Available online at : http://journal.unj.ac.id/unj/index.php/gjik

Gladi : Jurnal Ilmu Keolahragaan 12 (05) 2021, 378-395

Permalink/DOI: https://doi.org/10.21009/GJIK.125.05

\title{
THE EFFECT OF BALANCE, CONCENTRATION, AND COORDINATION ON DOLLYO CHAGI KICK SKILLS IN POPB TAEKWONDO ATHLETES IN DKI JAKARTA
}

\author{
Reggie Reginald ${ }^{1}$, Fahmy Fachrezzy ${ }^{1}$, Iwan Hermawan ${ }^{1}$ \\ Sports Education, Postgraduate State University of Jakarta, \\ Komplek Universitas Negeri Jakarta Gedung M. Hatta Jl. Rawamangun Muka, Jakarta Timur, Indonesia \\ 13220
}

Coresponding author. Email: reggiereginald12@gmail.com

\begin{abstract}
The aim of this research was to determine the direct and indirect effect as well as the simultaneous effect of exogenous variables with endogenous variables. The research method used was an associative quantitative approach using test and measurement techniques. The data analysis technique used was a path analysis approach. The population in this research was all of POPB DKI Jakarta athletes in 2021 totaling 20 people. The sampling technique used was total sampling so that the number of samples in this research was 20 people consisting of 10 women and 10 men. The skills of Dollyo Chagi Kick Taekwondo used the Dollyo Chagi Kick skills test. The balance used a modified bass test. The concentration used a concentration grid test. The instrument of eye-foot coordination used a smart speed pro coordination test. The results showed that the direct effect of variable $X_{1}$ on $Y=0,243$. The direct effect of variable $X_{2}$ on $Y=0,567$. The direct effect of variable $X_{3}$ on $Y=0,378$. The direct effect of variable $X_{1}$ on $X_{3}=0,706$. The direct effect of variable $X_{2}$ on $X_{3}=0,297$. The indirect effect of variable $X_{1}$ on $Y$ through $X_{3}=0,706 \times 0,378=$ 0,267 . The indirect effect of variable $X_{2}$ on $Y$ through $X_{3}=0,297 \times 0,378=0,113$.
\end{abstract}

Keywords: balance; concentration; coordination; dollyo chagi kick

\section{INTRODUCTION}

Taekwondo is growing rapidly and its practitioners have spread all over the world. "Taekwondo is arguably among the most important martial arts and combat sports worldwide in considering that it is an official Olympic sport practiced by several millions of athletes" (Pérez-Gutiérrez, ValdesBadilla, Gómez-Alonso, \& GutiérrezGarcía, 2015). At this time, there are about eighty million people who practice the martial arts of Taekwondo in various parts of the world this day.
Taekwondo matches are divided into three types: kyorugi or fighting, poomsae or moves, and kyukpa or breaking hard objects. Taekwondo is synonymous with kicks because most of the techniques used in matches are kicks. There are varied basic kicks in taekwondo, for instance; dollyo chagi (forward kick using the back of the foot from the side), ap chagi (straight forward kick), and yepo chagi (forward kick by pushing the soles of the feet towards the target). The kick of yeop chagi contributed to obtaining a relatively high 
score of $15 \%$ and the kick of dollyo chagi became the highest contributor as much as 28\% (Mansur, 2015). Furthermore, the kick of checking yeop chagi men as much as $15,96 \%$ and women as much as 10,28\%, dollyo chagi men as much as $20,11 \%$ and women as much as $13,74 \%$, and dollyo chagi men as much as $12,50 \%$ and women as much as $7,69 \%$ and the most effective for senior male taekwondo athletes kick used was dollyo chagi (Rachmahani, 2016). Based on the explanation above, the dollyo chagi kick technique is the most frequently used technique and has the greatest effectiveness for generating points during a match. Therefore, it is crucial for athletes to master this dollyo chagi kick technique.

The most commonly used and highly effective base kick in kyorugi matches is dollyo chagi kick (forward kick using the back of the feet from the side) or also known as roundhouse kick (Wojtaś, Unierzyski, \& Hurnik, 2017). The dollyo chagi kick is often used in daily practice and in taekwondo competitions, it has many uses and can be used to attack, defend, and counterattack opponents (Ervilha, Fernandes, Souza, \& Hamill, 2020). So this kick technique occurs a lot in matches both in senior and junior classes (Tan \& Krasilshchikov, 2015). The dollyo chagi kick or also known as roundhouse kick is also owned by many other martial arts branches such as kick boxing, pencak silat (sickle kick), and karate (Mawashi-Geri) (Petri, Bandow, Salb, \& Witte, 2019). Defined by Ouergui et al that the roundhouse kick is the hip performs rotational movement to the side: the legs and accompanying this rotation depict a circular arc from the outside to the inside and from the vertical plane to the horizontal plane to strike the opponent on the side (Ouergui, Hssin, Franchini, Gmada, \& Bouhlel, 2013).

Kick technique that can generate points is a technique determined by four factors, namely; concentration, coordination, accuracy, and impact. Concentration is needed when in the match, including when going to do kick techniques, with good concentration will create good coordination between the eyes that see the opponent and all parts of the body in order to help the attack technique come out. After the technique can be successfully come out, the next factor that determines whether a point is entered or not is accuracy and impact. A technique will get points if it hits a 
legitimate target area and generate an impact on the target of the opponent' body. Bio motor components developed in taekwondo sports include coordination, skill, speed, flexibility, muscle strength, balance, posture, power, and endurance (Tirtawirya, 2011).

Balance is one of the most important bio motor components for humans. According to (Widiastuti, 2015) "Balance is the ability to maintain the posture and position of the body quickly when standing (static balance) or when doing movements (dynamic balance)". The ability of the body to give the desired position when moving (Gürkan, 2016). Balance is the ability to maintain the body's center of mass over its base of support (Watson, Black, Crowson, 2016). Balance is divided into two, namely static to balance the body in a place or position and dynamic is the ability to balance movements (Zilvikar, 2016). Static balance refers to the ability to maintain equilibrium in a stationary fashion, whereas dynamic balance relates to the ability to maintain balance when the body is in motion (Shim \& Rose-Woodward, 2019). dynamic balance-a state in which a robust complex system will self-correct in response to imbalance (resulting from perceived variation/challenge) to maintain functional organization, or the individual and coordinated expression of balance and imbalance (Cowen, Nesti, \& Cheetham, 2014). Dynamic balance also has a positive relationship with the lower body strength in adults (Shim, Harr, \& Waller, 2018).

Athletes must have the awareness, knowledge, and ability to control their attention to concentrate effectively. (Cox, 2011) explained that all sports really require excellent concentration to support the performance of athletes when in matches. Joaquin Dosil in (Wibowo \& Gupita, 2020) stated that taekwondo is a sport of martial arts that requires psychological factors such as concentration, anticipation, emotional control, self-control, self-confidence, and fighting power. Concentration is a basic human psychological skill that is crucial to maintain mental toughness, especially in open skill sports where the environment moves quickly and constantly changes (Monsma, Perreault, \& Doan 2017). Concentration refers to the orientation or focus of a person's psychological activity on a particular object which is also one of the most 
important factor in carrying out effective learning activities (Yang, Zhao, Tian, \& Xing, 2020). (Komarudin, 2015) concentration in each individual has a difference between one and the other. Concentration enables people to exclude irrelevant information and focus on things or objects that attract them (Ma \& Wei, 2016). Good concentration is really needed when in taekwondo matches because it is an individual sport where an athlete must continue to fully concentrate on the entire time of the match. If the concentration is a little bit diverted then it will have a fatal impact for an athlete.

The situation in martial arts especially fighting numbers is very unpredictable. The duration of one kick only lasts less than one second so it also requires good coordination at the time of its implementation, because if it takes too long in doing it then the opponent will be able to see and the opportunity to get points will be lost. Coordination is the ability to perform movements or work appropriately and efficiently. One of the vital facts of human development is its coordination movement (Sogut, 2016). Coordination states the harmonious relationship of various factors that occur in a movement
(Widiastuti, 2015). Coordination is the ability of the performer to integrate types of body movement into specific patterns" (Babu \& Kumar, 2014). (Astanto, 2018) stated that in coordination will result timing and accuracy.

At this time, technological advances are very rapid in various fields including sports. The development of sports technology is very important to be used especially in Indonesia to increase the achievements of athletes both local and national. The development and advancement of sports technology is indispensable for the advancement of sports achievement (Syakur, Badruzaman, \& Paramitha, 2017). Digital tools are able to predict and direct someone to choose the right sport and various technologies to be able to produce high-achieving athletes (Yoda, 2020). Equipment from fusion sport.inc is one of the sports equipment development companies from Australia that has been used by national sports federations from various countries, Olympic committees, and many of the world' elite sports teams in its athlete development programs (Fusion, 2019). This equipment is equipment using a sensor that detects a movement that is 
usually used in measuring speed in running. However, in this study, this equipment will be modified and programmed to see the coordination of the eyes, the hands, and the legs.

The peak achievements of various sports are achieved around the age of $14-25$ years and the process of coaching athletes to achieve peak achievement takes approximately $6-10$ years (Nurjaya, 2012). Thus, the orientation of sports coaching must begin at an early age, namely when they are still in elementary school. The development of the sport should be done by paying attention to the characteristic of child, the process of growth, and the development of child. Coaching athletes should be done as early as possible in order to have sufficient time to prepare for the highest achievement. Sports coaching from an early age through structured and sustainable programs and through a good concept becomes a must where from the beginning sports coaching needs to be managed well in accordance with the principles of longterm sports coaching (Rasyono, 2016).

In DKI Jakarta Province has several athlete coaching posts such as PPOP, PPLM and Pelatda. In 2019, Dispora DKI Jakarta launched a new coaching program for the first time in Indonesia, namely coaching children under the age of 15 years old and continuity which was originally called PPOB (Sustainable Sports Development Program) then its name was changed to POPB (Sustainable Achievement Sports Program). Dispora collaborated with FIK UNJ to use LTAD (Long Term Athlete Development) based on sports science on the approach of this program, as well as for the selection process of the athletes, the coaches also provided expert teams such as sports doctors, sports psychologists, paramedics, and others.

A Canadian achievement sports coaching expert, Dr Istvan Balyi designed and compiled the stages of sports coaching into a clear and systematic stage for the development of long-term athletes called Long Term Athlete Development (LTAD). The stages are active start (age 0-6 years), fundamental (girls aged 6-8 years, boys aged 6-9 years), learn to train (girls aged 8-11 years, boys aged 9-12 years), train to train (girls aged 11-15 years, boys aged 12-16 years), train to compete (girls aged 15-21 years, boys aged 16-23 years) train to win (women over the age 
of 18 and men over the age of 19) and active for life (all ages) (Rizal, 2016).

The development of sports technology is crucial to be used especially in Indonesia to increase the achievements of athletes both local and national. Development and advancement of sports technology is necessary for the advancement of sports achievement (Syakur et al., 2017). Technology has also become a close part of sports, from the moment of the game to the moment of training and athletes' preparation. In the match, the use of technologies such as timekeeping systems used by sports is measured up to scoring systems using a sensor on the body protector in taekwondo sports. During the preparation period, technology is also used to help an athlete to achieve better performance and use digital test equipment that is more accurate in recording data.

Based on the background description that has been described above, the researchers are very interested in researching the effect of balance, concentration, and eye-foot coordination on dollyo chagi kick skills in POPB athletes in DKI Jakarta using tools such as fusion sport and kinovea application also concentration grid.

\section{METHOD}

In general, the aim of this study was to determine the effect between the three independent variables or exogenous, namely: balance, concentration, and eye-foot coordination with dependent variable or endogenous, namely: dollyo chagi kick skills as well as analyzing the correlation of independent variables (balance, concentration, and eye-foot coordination) on dependent variable (dollyo chagi kick skills) either directly or indirectly.

The research method used in this study was an associative quantitative approach using test and measurement techniques, while the analysis technique used was a path analysis. Path analysis is a technique to analyze a causal correlation that occur in multiple regressions if the independent variable affects the dependent variable, not only directly but also indirectly (Hakam, Sudarno, \& Hoyyi, 2015). According to (Sugiono, 2019) population is a generalized area consisting of objects or subjects which have certain qualities and characteristics that are applied by researchers to be studied and then drawn conclusions. Based on the explanation above, the population in this study will 
be all athletes of POPB DKI Jakarta in 2021 numbered 20 people

Sampling technique used in this study was total sampling. The reason for taking total sampling was because the population was less than 100. So the number of samples in this study was as many as 20 people consisting of 10 women and 10 men. Data collection technique used was research instrument tests. The dollyo chagi kick using dollyo chagi kick skills test. The balance using modified bass test. The concentration using concentration grid test and the eyefoot coordination using smart speed pro coordination test. The form of data analysis in this study were the form of numbers including: balance, concentration, coordination of eye-foothand and dollyo chagi kick skills. In accordance with the formulation of research methodologies and theoretical models that have been described, the analysis techniques used in testing this research hypothesis was path analysis.

\section{RESULT AND DISCUSSION}

\section{Result}

The collecting data of this study was using validated instruments for each variable. The values that had been obtained from raw data were then processed by descriptive statistical method using program of SPSS version 25.

\section{Data description}

\section{The variable of dollyo chagi skills (Y)}

Based on the results of the analysis of research data for the score of dollyo chagi skills, it can be seen that the average or mean value was 79,40 with a standard deviation was 3,872 , the range was 11, the smallest value or min was 72 and the highest value or max was 83 . The number of classes and frequency distributions on variable $\mathrm{Y}$ are seen in table 1

Table 1.

Dollyo Chagi Skills

\begin{tabular}{lll}
\hline $\begin{array}{l}\text { Interval } \\
\text { Class }\end{array}$ & $\begin{array}{l}\text { Absolute } \\
\text { Frequency }\end{array}$ & $\begin{array}{l}\text { Relative } \\
\text { Frequency }\end{array}$ \\
\hline $72-73$ & 4 & $20 \%$ \\
$74-75$ & 0 & $0 \%$ \\
$76-77$ & 1 & $5 \%$ \\
$78-79$ & 3 & $15 \%$ \\
$80-81$ & 3 & $15 \%$ \\
$82-83$ & 9 & $45 \%$ \\
TOTAL & $\mathbf{2 0}$ & $\mathbf{1 0 0 \%}$ \\
\hline
\end{tabular}

Based on the table above, it can be seen that in dollyo chagi kick skills variable there were 3 respondents (15\%) obtained an average score, 7 respondents (40\%) obtained a score below the average and 9 respondents (45\%) obtained a score above the average. 
2. The variable of balance $\left(X_{1}\right)$

Based on the results of the analysis of research data for the score of balance, it can be seen that the average or mean value was 70,55 with a standard deviation was 4,989, the range was 19 , the smallest value or min was 61 and the highest value or max was 80 . The number of classes and frequency distributions on variable $X_{1}$ are seen in table 2

Table 2.

Balance

\begin{tabular}{ccc}
\hline $\begin{array}{c}\text { Interval } \\
\text { Class }\end{array}$ & $\begin{array}{c}\text { Absolute } \\
\text { Frequency }\end{array}$ & $\begin{array}{c}\text { Relative } \\
\text { Frequency }\end{array}$ \\
\hline $61-65$ & 3 & $15 \%$ \\
$66-70$ & 7 & $35 \%$ \\
$71-75$ & 6 & $30 \%$ \\
$76-80$ & 3 & $15 \%$ \\
$81-85$ & 1 & $5 \%$ \\
TOTAL & $\mathbf{2 0}$ & $\mathbf{1 0 0 \%}$ \\
\hline
\end{tabular}

Based on the table above, it can be seen that in balance variable there were 6 respondents (30\%) obtained an average score, 10 respondents $(50 \%)$ obtained a score below the average and 4 respondents $(20 \%)$ obtained a score above the average.

3. The variable of concentration $\left(X_{2}\right)$

Based on the results of the analysis of research data for the score of concentration, it can be seen that the average or mean value was 50 with a standard deviation was 9,91 , the range was 38 , the smallest value or min was 24 and the highest value or max was 62 . The number of classes and frequency distributions on variable $\mathrm{X}_{2}$ are seen in table 3 .

Table 3.

Concentration

\begin{tabular}{ccc}
\hline $\begin{array}{c}\text { Interval } \\
\text { Class }\end{array}$ & $\begin{array}{c}\text { Absolute } \\
\text { Frequency }\end{array}$ & $\begin{array}{c}\text { Relative } \\
\text { Frequency }\end{array}$ \\
\hline $24-30$ & 1 & $5 \%$ \\
$31-37$ & 0 & $0 \%$ \\
$38-44$ & 4 & $20 \%$ \\
$45-51$ & 5 & $25 \%$ \\
$52-58$ & 5 & $25 \%$ \\
$59-65$ & 5 & $25 \%$ \\
TOTAL & $\mathbf{2 0}$ & $\mathbf{1 0 0 \%}$ \\
\hline
\end{tabular}

Based on the table above, it can be seen that in concentration variable there were 5 respondents $(25 \%)$ obtained an average score, 5 respondents (25\%) obtained a score below the average and 10 respondents $(50 \%)$ obtained a score above the average.

4. The variable of eye-foot coordination $\left(\mathbf{X}_{3}\right)$

Based on the results of the analysis of research data for the score of foot-eye coordination, it can be seen that the 
average or mean value was 75 with a standard deviation was 4,484 , the range was 14, the smallest value or min was 68 and the highest value or max was 82 . The number of classes and frequency distributions on variable $X_{3}$ are seen in table 4.

Table 4.

Eye-foot coordination

\begin{tabular}{ccc}
$\begin{array}{c}\text { Interval } \\
\text { Class }\end{array}$ & $\begin{array}{c}\text { Absolute } \\
\text { Frequency }\end{array}$ & $\begin{array}{c}\text { Relative } \\
\text { Frequency }\end{array}$ \\
\hline $61-65$ & 3 & $15 \%$ \\
$66-70$ & 7 & $35 \%$ \\
$71-75$ & 6 & $30 \%$ \\
$76-80$ & 3 & $15 \%$ \\
$81-85$ & 1 & $5 \%$ \\
TOTAL & $\mathbf{2 0}$ & $\mathbf{1 0 0 \%}$ \\
\hline
\end{tabular}

Based on the table above, it can be seen that in eye-foot coordination variable there were 6 respondents $(30 \%)$ obtained an average score, 10 respondents $(50 \%)$ obtained a score below the average and 4 respondents (20\%) obtained a score above the average.

\section{Hypothesis Test}

\section{Sub Structure I}

Sub structure I showed the combined and partial effect of balance and concentration on eye-foot coordination. The results of the statistic calculation can be seen in the summary table in table 5.

Table 5.

Model Summary

Std. Error

$\mathrm{R}$ Adjusted $\mathrm{R}$ of the

Model R Square Square Estimate

\begin{tabular}{lllll}
1 & $.711^{\mathrm{a}}$ & .506 & .448 & 3.333 \\
\hline a. Predictors: (Constant), X2, X1 & \\
b. Dependent Variable: X3
\end{tabular}

The number of R square $\left(\mathrm{r}^{2}\right)$ was

0,506 which can be used to determine the effect of balance and concentration on eye-foot coordination. The figure showed that the effect of balance and concentration on eye-foot coordination was 0,506 or $50,6 \%$ as for the remaining $49,4 \%$ was influenced by other factors. In other words, the variability of eyefoot coordination can be explained using the variable of balance and concentration was $50,6 \%$ while the effect was $49,4 \%$ caused by other variables outside the model.

Structural equations of sub structure I can be made from table 6

Table 6.

Coefficients

Unstandardized

Coefficients

Model B Std. Error

1 (Constant) $29.554 \quad 11.080 \quad 2.667$ 
Gladi Jurnal Ilmu Keolahragaan, 12 (05), Desember- 387

Reggie Reginald, Fahmy Fachrezzy, Iwan Hermawan

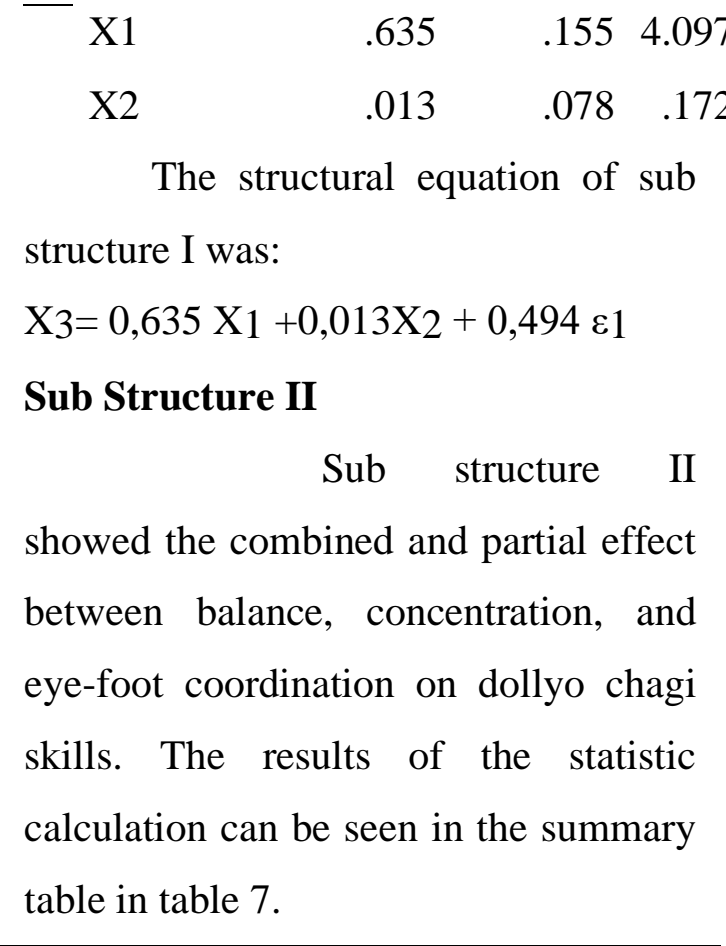

Table 7.

Model Summary

\begin{tabular}{|c|c|c|c|c|}
\hline & & $\mathrm{R}$ & $\begin{array}{c}\text { Adjuste } \\
\text { d R }\end{array}$ & $\begin{array}{l}\text { Std. Error } \\
\text { of the }\end{array}$ \\
\hline Model & $\mathrm{R}$ & Square & Square & Estimate \\
\hline \multirow[t]{2}{*}{1} & $.747^{\mathrm{a}}$ & .558 & .475 & 2.806 \\
\hline & Predic & tors: (Co & nstant), $X$ & $3, \mathrm{X} 2, \mathrm{X} 1$ \\
\hline
\end{tabular}

The number of $\mathrm{R}$ square $\left(\mathrm{r}^{2}\right)$ was 0,558 which can be used to determine the effect of balance, concentration, eyefoot coordination on dollyo chagi skills. The figure showed that the effect of balance, concentration, and eye-foot coordination on dollyo chagi skills was 0,558 or $55,8 \%$ as for the remaining $44,2 \%$ was influenced by other factors. In other words, the variability of dollyo chagi skills can be explained using the variable of balance, concentration, and eye-foot coordination was $55,8 \%$ while the effect was $44,2 \%$ caused by other variables outside the model.

\section{Structural equations of sub structure}

\section{II can be made from table 8}

\begin{tabular}{|c|c|c|c|}
\hline \multirow[b]{2}{*}{ Model } & \multicolumn{2}{|c|}{$\begin{array}{l}\text { Unstandardized } \\
\text { Coefficients }\end{array}$} & \multirow[b]{2}{*}{$\mathrm{t}$} \\
\hline & B & $\begin{array}{l}\text { Std. } \\
\text { Error }\end{array}$ & \\
\hline \begin{tabular}{|l|l|}
1 & (Constant)
\end{tabular} & 52.656 & 11.111 & 4.739 \\
\hline X1 & .189 & .184 & 1.027 \\
\hline $\mathrm{X} 2$ & .222 & .066 & 3.372 \\
\hline X3 & .327 & .204 & 1.600 \\
\hline a. D & lent $\mathrm{Va}$ & able: Y & \\
\hline
\end{tabular}

The structural equation of sub structure II was:

$\mathrm{Y}=0,189 \mathrm{X} 1+0,222 \mathrm{X} 2+0,327 \mathrm{X} 3+$ $0,442 \varepsilon 2$

\section{DISCUSSION}

\section{The direct effect of balance on} dollyo chagi kick skills

Balance is one of the important factors in supporting daily activities or sport. Based on the results of the data analysis of research showed that the balance had a direct effect on dollyo chagi kick skills. The results of the data analysis showed that the significance value of the direct effect of balance on dollyo chagi kick skills was 0,032 < 0,05 , so the balanced had an effect on 
dollyo chagi kick skills with the beta coefficient value of 0,243 . An athlete who has good balance will generate good kick skills too.

When doing kicks, the position of the body rests on only one leg, hence a good balance is needed for athletes to be able to perform good kicking techniques as a result of previous research which stated that balance is necessary because it has a significant correlation to the technical skills of an athlete both in the sport of the game (Zulman, Umar, \& Atradinal, 2018) and in martial arts sports (Iskandar \& Rismayadi, 2019)

\section{The direct effect of concentration} on dollyo chagi kick skills

Concentration is the ability of someone to focus on one particular act so that other stimulus from both the outside and inside will not interfere. The results of the data analysis showed that the value of concentration signification directly influenced dollyo chagi kick skills $0,004<0,05$, so the concentration influenced on dollyo chagi kick skills with the beta coefficient value was 0,567. An athlete who has good concentration will generate good kick skill as well.

Concentration in athletes is needed when in a match because if athletes lose their concentration then it will be fatal, either getting defeat or injury. Concentration become a factor that must be considered and improved because it has a positive correlation with skills in sports (Taufik, 2019), including when doing kicks, concentration also has a role in kick speed (Ihsan, 2018)

\section{The direct effect of eye-foot} coordination on dollyo chagi kick skills

Coordination is the ability of someone to perform an activity involving a series of aligned movements of several body parts. Eye-foot coordination is coordination where the eye is a mean of receiving stimuli from the outside and the feet is other limbs that perform movements according to the needed pattern and rhythm. The results of the data analysis showed that the value of eye-foot coordination signification directly influenced dollyo chagi kick skills $0,013<0,05$, so the eye-foot coordination influenced on dollyo chagi kick skills with the beta coefficient value was 0,378 . An athlete who has good eye-foot coordination will generate good kick skills as well.

Sports activity frequently needs complex movements so that is required coordination of several body parts. By 
having good coordination, it will help a person in doing sports activities also technical skills, this is in line with previous research which stated that the skills of students will increase if the level of their coordination increases as well (Nurhidayah \& Sukoco, 2015). When doing kick techniques, it is necessary to coordinate between the eyes to see the position of the body to see the target or opponent and the legs as the execution of the movements, so that eyefoot coordination has a direct effect on kick skills.

\section{The direct effect of balance on} eye-foot coordination

Balance is one of the important factors in daily activities including when doing movements that require coordination. The results of the data analysis showed that the value of balance signification directly influenced eye-foot coordination $0,001<0,05$, so the balance directly influenced on the eye-foot coordination with the beta coefficient value was 0,706 . An athlete who has good coordination will generate good eye-foot coordination as well. In line with the theory of Radwan in Internation Journal of Science Culture which stated that "The special coordination abilities for athlete include each of the motor adaptation and adjustment ability, the ability to differentiate, reaction speed ability, orientation ability, balance ability, 6 coupling ability, the ability to sense the rhythm" so the balance is one of the ability of coordination (Radwan, 2014).

\section{The direct effect of concentration on eye-foot coordination}

Concentration is the ability of someone to focus on one particular act so that other stimulus from both the outside and inside will not interfere. The results of the data analysis showed that the value of concentration signification directly influenced eye-foot coordination $0,035<0,05$, so the concentration influenced on eye-foot coordination with the beta coefficient value was 0,297. An athlete who has good concentration will generate good eye-foot coordination as well. This is in line with previous research was conducted on volleyball athletes which stated that there was a direct effect of concentration on coordination of 35,16\% (Asdi, Rifki, 2020)

\section{The effect of balance on dollyo chagi kick skills through eye-foot coordination}

Balance is one of the important factors in daily activities including when 
doing kick movements because at the time of doing kick the body will only rest on one leg. The results of the data analysis showed that the balance had an effect on the eye-foot coordination of $49,8 \%$ and the eye-foot coordination had an effect on the dollyo chagi kick skills of $14,3 \%$. And the indirect effect of the balance on the dolly kick was $26,7 \%$. On kick movements is needed several body parts to generate a good technique. Coordination has a direct effect on balance and technical skills (Hidayat, 2018).

7. The effect of concentration on dollyo chagi kick skills through eye-foot coordination

Concentration is the ability of someone to focus on one particular act so that other stimulus from both the outside and inside will not interfere. The results of the data analysis showed that the concentration had an effect on the eye-foot coordination of $8,82 \%$ and the eye-foot coordination had an effect on the dolluyo chagi kick skills of $14,3 \%$. And the indirect effect of the concentration on the dollyo chagi kick skills was $11,3 \%$. Concentration and coordination determine the outcome of a technique in sports, because if athlete have good concentration and coordination, they will be able to control the course of the game by influencing the results of the techniques used in the game (Hanief \& Purnomo, 2019; Irawan, Permana, Akromawati, \& Yangtian, 2019).

\section{CONCLUSION}

1. There was a significant effect of balance $\left(\mathrm{X}_{1}\right)$ on dollyo chagi kick skills (Y). It can be concluded that the better the balance, the better the dollyo chagi kick skills will be generated. On the contrary, the lower the balance, the lower the dollyo chagi kick skills will be generated.

2. There was an effect of concentration $\left(\mathrm{X}_{2}\right)$ on dollyo chagi kick skills (Y). It can be concluded that the better the concentration, the better the dollyo chagi kick skills will be generated. On the contrary, the lower the concentration, the lower the dollyo chagi kick skills will be generated.

3. There was an effect of eye-foot coordination $\left(\mathrm{X}_{3}\right)$ on dollyo chagi kick skills (Y). It can be concluded that the better the eye-foot coordination, the better the dollyo chagi kick skills will be generated. On the contrary, the lower the eyefoot coordination, the lower the 
dollyo chagi kick skills will be generated.

4. There was an effect of balance $\left(\mathrm{X}_{1}\right)$ on eye-foot coordination $\left(\mathrm{X}_{3}\right)$. It can be concluded that the better the balance, the better the eye-foot coordination will be generated. On the contrary, the lower the balance, the lower the eye-foot coordination will be generated.

5. There was an effect of concentration $\left(\mathrm{X}_{2}\right)$ on eye-foot coordination $\left(\mathrm{X}_{3}\right)$. It can be concluded that the better the concentration, the better the eye-foot coordination will be generated. On the contrary, the lower the balance, the lower the eye-foot coordination will be generated.

6. There was an indirect effect of balance $\left(\mathrm{X}_{1}\right)$ on dollyo chagi kick skills (Y) through eye-foot coordination $\left(\mathrm{X}_{3}\right)$. It can be concluded that the better balance will generate good eye-foot coordination, so it will result good dollyo chagi kick skills as well. On the contrary, the lower the balance, the lower the eye-foot coordination, resulting in lower dollyo chagi kick skills

7. There was an indirect effect of concentration $\left(\mathrm{X}_{2}\right)$ on dollyo chagi kick skills (Y) through eye-foot coordination $\left(\mathrm{X}_{3}\right)$. It can be concluded that the better concentration will generate good eye-foot coordination, so it will result good dollyo chagi kick skills as well. On the contrary, the lower the concentration, the lower the eyefoot coordination, resulting in lower dollyo chagi kick skills.

\section{REFERENCES}

Asdi, F., \& Rifki, M. S. (2020). Pengaruh Daya Ledak Otot Tungkai, Koordinasi Mata Tangan Dan Konsentrasi Terhadap Kemampuan Block Bolavoli. Sporta Saintika, 5(2), 176-190. https://doi.org/10.24036/sporta.v $5 \mathrm{i} 2.142$

Astanto, B. D. (2018). HUBUNGAN ANTARA KOORDINASI MATA-TANGAN DAN KELINCAHAN TERHADAP KONSISTENSI FOREHAND GROUNDSTROKE DAN BACKHAND GROUNDSTROKE DALAM BERMAIN TENIS MAHASISWA PRODI PJKR FIK UNY. Jurnal Pendidikan Jasmani Dan Rekreasi-S1, 7(08), $1-14$.

Babu, M. S., \& Kumar, P. P. S. P. (2014). Effect of Continuous Running Fartlek and Interval Training on Speed and Coordination among Male Soccer Players I . Introduction Aerobic Physical work out are done with oxygen . Use of oxygen in the body metabolic or energy generating 
process to perform th. Journal of Physical Education and Sports Management, 1(1), 33-41.

Cowen, A. P., Nesti, M. S., \& Cheetham, M. (2014). The Psychology of Dynamic Balance and Peak Performance in Sport: Correction Theory. Quest, 66(4), 421-432. https://doi.org/10.1080/0033629 7.2014.936620

Cox, Ri. H. (2011). Sport Psychology Concepts and Applications (Second Edition). Journal of Sport and Exercise Psychology (Vol. 14). Mc Graw Hill. https://doi.org/10.1123/jsep.14.2 .222

Ervilha, U. F., Fernandes, F. de M., Souza, C. C. de, \& Hamill, J. (2020). Reaction time and muscle activation patterns in elite and novice athletes performing a taekwondo kick. Sports Biomechanics, 19(5), 665-677. https://doi.org/10.1080/1476314 1.2018.1515244

Fusion, S. (2019). About Fusion Sport.

Gürkan, A. C. (2016). Comparison of right- and left-leg balance points in female volleyball players and sedentary controls. Anthropologist, 24(3), 746-750. https://doi.org/10.1080/0972007 3.2016.11892071

Hakam, M., Sudarno, \& Hoyyi, A. (2015). Analisis Jalur Terhadap Faktor-Faktor Yang Mempengaruhi Indeks Prestasi Kumulatif (Ipk) Mahasiswa Statistika Undip. Jurnal Gaussian, 4(1), 61-70.

Hanief, Y. N., \& Purnomo, A. M. I. (2019). Petanque: Apa saja faktor fisik penentu prestasinya? Jurnal Keolahragaan, 7(2), 116-125. https://doi.org/10.21831/jk.v7i2.
26619

Hidayat, A. (2018). Pengaruh Daya Ledak Tungkai, Koordinasi Mata, Kaki dan Keseimbangan Terhadap Kemampuan Shooting Ke Gawang Pada Permainan Sepakbola Siswa SMA Negeri 14 Sinjai. Program Pascasarjana Universitas Negeri Makassar, 114.

Ihsan, N. (2018). Sumbangan Konsentrasi terhadap Kecepatan Tendangan Pencak Silat. Sumbangan Konsentrasi Terhadap Kecepatan Tendangan Pencak Silat, 8(1), 1-6. https://doi.org/10.15294/miki.v8 i1.11873

Irawan, F. A., Permana, D. F. W., Akromawati, H. R., \& Yang-tian, H. (2019). Biomechanical Analysis of Concentration and Coordination on The Accuracy in Petanque Shooting. Journal of Physical Education, Sport, Health and Recreations, 8(2), 96-100.

Iskandar, F. A., \& Rismayadi, A. (2019). Jurnal Kepelatihan Olahraga , Universitas Pendidikan Indonesia Penerapan Latihan Media Bosu Ball terhadap Peningkatan Keseimbangan Atlet Bolabasket. Jurnal Kepelatihan Olahraga, 11 (1), 51-58.

Komarudin. (2015). Psikologi Olahraga Lartihan Keterampilan Mental dalam Olahraga Kompetitif. (Y. Hidayat, Ed.) (1st ed.). Remaja Rosdakarya.

Ma, M. Y., \& Wei, C. C. (2016). A comparative study of children's concentration performance on picture books: age, gender, and media forms. Interactive 
Learning Environments, 24(8), 1922-1937.

https://doi.org/10.1080/1049482

0.2015 .1060505

Mansur, L. K. (2015). EFEKTIVITAS

TENDANGAN YEOP CHAGI

TERHADAP PEROLEHAN

NILAI PADA WORLD

TAEKWONDO GRAN-PRIX

FINAL TAHUN 2014 DI MEXICO. Universitas Negeri Yogyakarta.

Monsma, E., Perreault, M., \& Doan, R. (2017). Focus! Keys to Developing Concentration Skills in Open-skill Sports. Journal of Physical Education, Recreation \& Dance, 88(7), 51-55. https://doi.org/10.1080/0730308 4.2017.1340207

Nurhidayah, \& Sukoco, P. (2015). Pengaruh Model Latihan Dan Koordinasi Terhadap Keterampilan Siswi Ekstrakurikuler Bola Basket Smpn I Bantul. Jurnal Keolahragaan, 3(1), 66-78. https://doi.org/10.21831/jk.v3i1. 4970

Nurjaya, R. N. (2012). PEMBINAAN ATLET JANGKA PANJANG CABOR ROWING LTAD (Long-Term Athlete Depelovment). PEMBINAAN ATLET JANGKA PANJANG CABOR ROWING LTAD, 4(2), 108-123.

Ouergui, I., Hssin, N., Franchini, E., Gmada, N., \& Bouhlel, E. (2013). Technical and tactical analysis of high level kickboxing matches. International Journal of Performance Analysis in Sport, 13(2), 294-309. https://doi.org/10.1080/2474866 8.2013.11868649
Pérez-Gutiérrez, M., Valdes-Badilla, P., Gómez-Alonso, M. T., \& Gutiérrez-García, C. (2015). Bibliometric analysis of taekwondo articles published in the web of science (1989-2013). Ido Movement for Culture, 15(3), 27-34. https://doi.org/10.14589/ido.15.3 .4

Petri, K., Bandow, N., Salb, S., \& Witte, K. (2019). The influence of facial expressions on attack recognition and response behaviour in karate kumite. European Journal of Sport Science, 19(4), 529-538. https://doi.org/10.1080/1746139 1.2018 .1536170

Rachmahani, W. (2016). Efektivitas Tendangan Checking Yeop Chagi, Dollyo Chagi Dan Idan Dollyo Chagi Dalam Membuka Serangan Di Upi Challenge National Taekwondo Championship Tahun 2016 Effectiveness of Checking Yeop Chagi, Dollyo Chagi and Idan Dollyo Chagi in Opening the Atta. Pendidikan Jasmani Kesehatan dan Rekreasi. Universitas Negeri Yogyakarta.

Radwan, S. G. (2014). The impact of development of the special coordination abilities on the general skill ability for table tennis juniors under 12 years old. International Journal of Science Culture and Sport, 2(4), 30-30. https://doi.org/10.14486/ijscs71

Rasyono. (2016). Ekstrakurikuler Sebagai Dasar Pembinaan Olahraga Pelajar. Journal of Physical Education Health and Sport, 3(1), 44-49. https://doi.org/10.15294/jpehs.v 3i1.6501 
Rizal, doni. (2016). PEMBINAAN ATLET USIA MUDA. Jurnal Performa Olahraga, 1(02 SEArticles).

https://doi.org/10.24036/jpo8501 9

Shim, A., Harr, B., \& Waller, M. (2018). Does a Relationship Exist Between Lower Body Power and Balance Scores Among Older Adults? The Permanente Journal, 22, 1-4. https://doi.org/10.7812/TPP/17096

Shim, A., \& Rose-Woodward, J. (2019). Dynamic Balance Drills to Promote Skill Acquisition and Prevent Injuries in Children. Strategies, 32(3), 3-11. https://doi.org/10.1080/0892456 2.2019 .1585703

Söğüt, M. (2016). Gross motor coordination in junior tennis players. Journal of Sports Sciences, 34(22), 2149-2152. https://doi.org/10.1080/0264041 4.2016.1211311

Sugiono. (2019). Metode Penelitian Kuantitatif, Kualitatif, dan $R \& D$. ALFABETA.

Syakur, M. A., Badruzaman, , \& Paramitha, S. T. (2017). Pengembangan Alat Bantu Latihan Pelontar Bola Futsal Berbasis Mikrokontroler Dengan Menggunakan Software Pemograman Arduino. Jurnal Terapan Ilmu Keolahragaan, 2(1), 29. https://doi.org/10.17509/jtikor.v $2 \mathrm{i} 1.4963$

Tan, Y. L., \& Krasilshchikov, O. (2015). Diversity of attacking actions in Malaysian junior and senior taekwondo players. International Journal of Performance Analysis in Sport, 15(3), 913-923. https://doi.org/10.1080/2474866 8.2015.11868840

Taufik, M. S. (2019). Hubungan Tingkat Konsentrasi Dengan Keterampilan Bermain Futsal Unit Kegiatan Mahasiswa Futsal Universitas Suryakancana. Gladi: Jurnal Ilmu Keolahragaan, 10(02), 68-78. https://doi.org/10.21009/gjik.10 2.01

Tirtawirya, D. (2011). Agility T Test Taekwondo. Jurnal Olahraga Prestasi, 7(7), 27-31. https://doi.org/10.21831/jorpres. v7i7.10283

Watson, M. A., Black, O., \& Crowson, M. (2016). The Human Balance System: A Complex Coordination of Central and Peripheral Systems. Vestiblar Disorders Association, 1-4.

Wibowo, A. T., \& Gupita, E. C. (2020). Karakteristik Psikologis Pemain Futsal Kabupaten Sleman dalam Ajang PORDA Yogyakarta Tahun 2019. Program Studi Pendidikan Jasmani Dan Kesehatan, $\quad 08(22)$. https://doi.org/https://doi.org/10. 32682/bravos.v8i2.1505

Widiastuti. (2015). TES DAN PENGURUKAN OLAHRAGA. PT. RajaGrafindo Persada.

Wojtaś, A., Unierzyski, P., \& Hurnik, E. (2017). Fitness and skill performance characteristics of Polish female national taekwondo squad members. International Journal of Performance Analysis in Sport, 7(3), $\quad 1-8$. https://doi.org/10.1080/2474866 8.2007.11868404

Yang, X., Zhao, X., Tian, X., \& Xing, B. 
Gladi Jurnal Ilmu Keolahragaan, 12 (05), Desember- 395

Reggie Reginald, Fahmy Fachrezzy, Iwan Hermawan

(2020). Effects of environment and posture on the concentration and achievement of students in mobile learning. Interactive Learning Environments, O(0), 114.

https://doi.org/10.1080/1049482 0.2019 .1707692

Yoda, I. K. (2020). Peran Olahraga Dalam Membangun Sdm Unggul Di Era Revolusi Industri 4.0. Jurnal IKA, 18(1), 1-22.

Zulman, Umar, A., \& Atradinal. (2018). Keterampilan Sepak Sila Pemain Sepaktakraw Smp Negeri 2 Batang Anai. Jurnal Menssana, 3, 77-88. https://doi.org/10.24036/jm.v3i1 .68

Zulvikar, J. (2016). Pengaruh Latihan Core Stability Statis (Plank dan Side Plank) dan Core Stability Dinamis (Side Lying Hip Abduction dan Oblique Crunch) Tterhadap Keseimbangan. Journal of Physical Education Health and Sport, 3(2), 96-103. https://doi.org/10.15294/jpehs.v 3i2.6550 